\title{
Morphofunctional and motor characteristics of Baikal region's students (Russia) with overweight
}

\author{
Kolokoltsev M.M. ${ }^{1}$, Iermakov S.S. ${ }^{2}$ \\ ${ }^{1}$ Department of the Physical Culture, Irkutsk National Research Technical University, Russia \\ ${ }^{2}$ Department of Tourism and Recreation, Gdansk University of Physical Education and Sport, Poland
}

Authors' Contribution: A - Study design; B - Data collection; C - Statistical analysis; D - Manuscript Preparation; E - Funds Collection.

\begin{abstract}
Purpose: $\quad$ to study the morphofunctional and motor characteristics of the organism of students with overweight and obesity. To compare these data with data of students with normal weight.

Material: $\quad$ it was examined students (females $-\mathrm{n}=1937$; males $-\mathrm{n}=1302$ ) of 17-21 year-olds. (Baikal region, Russia). It was performed an anthropometrical and physiometric examination of students. It was determined the content of muscle and fat mass in the component structure of a body. It was determined the motor qualities of students.

Results: $\quad$ the indicators of anthropometrical and physiometric characteristics, results of motor action tests, the content of muscle and fat mass in a body of students with overweight and obesity are lower in comparison with the indicators of females and males with normal body weight $(p<0.05)$. The integral criterion of physical fitness of students with overweight and obesity is lower in comparison with students with normal body weight $(p<0.05)$. It is defined the direct dependence between the decrease in the level of physical fitness and increase in body weight of males and females. It was obtained data concerning interrelation of anthropometrical and functional characteristics with motor qualities of males and females with different body weight.

Conclusions: $\quad$ Results of the research allow correcting physical training classes of youth. Such classes are focused on the differentiated decrease in fat mass content and increase in muscle mass in the component structure of students' bodies.

Keywords: students, anthropometrical, physiometric, motor qualities, overweight.
\end{abstract}

\section{Introduction}

According to World Health Organization (WHO) 39\% of adult population of the world had overweight, and 13\% had obesity in 2016 [1]. In European countries overweight had $50 \%$ of the population: among them $20 \%$ had obesity $[2,3]$. There are a lot of people with overweight in a population of USA, Australia, Great Britain, China, South Korea, in the countries of Near East $[4,5]$. WHO experts presuppose that the number of people in the world with obesity or overweight will double by 2025 .

Overweight in youth strengths researchers to look for more effective ways to solve this problem:

- for New York students - consultations with healthcare providers [6];

- for Brazilian teenagers - control of obesity. It will allow decreasing the prevalence of hypertension in Northern region [7];

- for the youth of USA - it is the introduction of the monitoring system of risks behavior [8]. Six categories of health priority types among youth need the control: 1) behaviors that contribute to unintentional injuries and violence; 2) tobacco use; 3) alcohol and other drug use; 4) sexual behaviors related to unintended pregnancy and sexually transmitted infections (STIs), including human immunodeficiency virus (HIV) infection; 5) unhealthy dietary behaviors; and 6) physical inactivity [8];

- for Australian schoolchildren - it is the need to change habits concerning nutrition and to create healthy cultures in schools [9];

C) Kolokoltsev M.M., Iermakov S.S., 2019

doi:10.15561/18189172.2019.0101
- for the youth of developing countries - the actions for obesity prevention which have to be innovative, concrete for the country and accepted from the cultural point of view [10];

- for Chinese youth - experts have to pay more attention to the prevalence of overweight and obesity in rural regions [11].

It is especially important to consider regional features in the prevention of obesity among youth. Such approach is in researches of regional features of Iran [12], Portugal [13], Sudan [14], Greece [15], Puerto Rico [16], Taiwan [17], Latin America [18], Ethiopia [19], Canada [20]; Republic of Belarus [21], Lithuania [22]. Authors confirm that the competence in the field of health care became an important part of the agenda in the field of healthcare and strengthening of health in recent years.

By results of a research (2012-2013) in 12 territorial subjects of Russian Federation, the prevalence of obesity among men was $26.9 \%$, among women - 30.8\% [23]. The annual growth of obesity cases in Russia is $0.4 \%$ in a year [2]. The overweight and obesity are widespread among students, especially after 20 year old [2]. Among students of the medical higher educational institution of Kemerovo (Russia), overweight have $10.7 \%$, obesity have 4.8\%, underweight have 9.7\% [24]. In Tomsk (Russia) overweight have $18.6 \%$ of male-students [25].

Morphofunctional characteristics of the person are considered by researchers as information criteria of hormonal, growth and other metabolic processes; features of influence on the organism of climatic, ecological, 
social and others factors [26, 27]. Therefore it is necessary to evaluate morphofunctional indicators of the population of different regions taking into consideration the regional anthropological features of persons.

The specialists of WHO emphasize the increase in a number of persons with overweight and obesity. It is especially widespread among city population. In this case process of urbanization is especially expressed, in comparison with rural population [1]. The Baikal region (Russia) is characterized by strongly continental climate. This region is also characterized by the adverse ecological situation connected with human impact [28]. Researchers point out regional features of body structure types of Baikal region's youth ${ }^{5}$. Authors determined incompleteness of body growth processes of Siberia youth (Russia) in comparison with students from the European part of Russia [29]. It is relevant the study of a regional feature of overweight and obesity prevalence among Baikal region's youth (Russia). The basis of such researches is made by motor action characteristics of students. These problems in this region haven't been studied yet.

The overweight and obesity promote the development of a serious noninfectious illness. It is diabetes of 2 nd type, atherosclerosis, arterial hypertension, osteoarthrosis, varicosity [30] violation of coronary and brain blood supply [31]. The risk of development of coronary heart disease in people with obesity increases in 2-3 times, strokes in 7 times [32]. People with the big body-weight index have violations of hormonal state [25]. Their working capacity [33, 34] and lifetime [35] decrease. The reason for an increase in the level of obesity is the availability of high-calorie foods against in a complex with a decrease in physical activity of population $[36,37]$.

The low physical activity has $39.8 \%$ of Russian population: $37.0 \%$ of men and $42.0 \%$ of women [23]. In researches of WHO [38] was emphasized the necessity to prevention and fight against obesity; normalization of population nutrition of various countries; to prevention addictions. The important role of people's physical activity is defined: increase in volumes and quality of physical training programs in educational institutions of different types [39, 40]; attraction to active sports activities and health-promoting activities [41, 42]; pedagogical control for physical loads $[43,44]$. Training with students by a traditional technique (2-3 times a week) doesn't give the positive result concerning the decrease in body weight [40]. Therefore it is necessary to introduce the corrective classes in non-school hours [45].

The considerable decrease in overweight is promoted by application of health-promoting activities [46, 47, 48], physical exercises in a complex with a balanced diet and day regimen $[49,50]$; corporal focused and dancing psychocorrection [51]; consideration of women's body features [52]; control of psychophysiological functions [53]. Other researches support the need of carrying out the fundamental and applied scientific researches in the field of primary population prevention of noninfectious diseases and formation of to a healthy lifestyle requirement [23] in population.
Hypothesis. The data concerning the interrelation of morphofunctional indicators with motor qualities of students with overweight and obesity will allow adding individual specific orientation of means and methods of carrying out physical training classes for university students.

Purpose: the comparative analysis of morphofunctional features and motor action characteristics of an organism of Baikal region's students (Russia) with overweight and obesity.

\section{Materials and Methods}

\section{Participants}

The university students (Irkutsk, Russia) were examined: females $(n=1937)$, males $(n=1302), 17-21$ year-olds. All students belonged to the main medical group (have no deviations of health condition). The performed work doesn't violate the right and doesn't endanger the wellbeing of students in compliance with Ethical Principles for Medical Research Involving Human Subjects [54].

Design of a research.

It is carried out the anthropometrical and physiometric examination of females and males with an application of standard techniques [55]. It is calculated weight-forheight Quetelet index II (BMI= body mass/body height ${ }^{2}$, $\mathrm{kg} / \mathrm{m}^{2}$ ) [56]. According to WHO classification (1991) [57] students are devoted into 4 groups: group " $\mathrm{N}$ " with normal body weight (BMI is in the range of 18.5-24.99 $\mathrm{kg} / \mathrm{m}^{2}$ ); group "OV" with overweight $\left(\mathrm{BMI}=25-30 \mathrm{~kg} / \mathrm{m}^{2}\right)$; group "OB" with obesity (BMI $\left.>30 \mathrm{~kg} / \mathrm{m}^{2}\right)$; group "U" with underweight $\left(B M I<18.5 \mathrm{~kg} / \mathrm{m}^{2}\right)$. It was measured for the characteristic of morphofunctional indicators:

- body height, cm;

- body weight, kg;

- chest circumference (CC), cm;

- circumference of body parts, $\mathrm{cm}$;

- skinfold thickness (caliperometry), mm;

- heart rate (HR) before load, b/10 s;

- HR after 20 squats in $30 \mathrm{~s}, \mathrm{~b} / 10 \mathrm{~s}$;

- HR recovery time after 20 squats, min;

- systolic arterial blood pressure (ABPs), mmHg;

- diastolic arterial blood pressure (ABPd), $\mathrm{mmHg}$;

- vital capacity lung (VCL), 1;

- hand-held dynamometry, $\mathrm{kg}$.

It was calculated: Robinson [58] index $\left(\mathrm{Rob}_{\text {index }}=\right.$ HRxABPs: 100. c.u.); vital index (VI = VCL/body weight [59], $\mathrm{ml} / \mathrm{kg}$ ); strong index ( $\mathrm{SI}=$ muscle strength of hand/ body weight $\mathrm{x} 100 \%$ ) [60]. It was defined the average value of absolute and percentage content in students' bodies of fat and muscular tissue according to the formulas [61]. It was applied the control tests included in the European and American tests of physical fitness [62,63] to evaluate the physical fitness of students (high-speed qualities, endurance, strength, flexibility, dexterity). For females: $20 \mathrm{~m}$ run (s); 10x5 m shuttle run (s); 5 min run (min); hang (s); sit-ups (quantity of times); trunk bending $(\mathrm{cm})$; long jump from the spot $(\mathrm{cm})$. For males: $100 \mathrm{~m}$ run (s); 1000 $\mathrm{m}$ run (min); 10x5 m shuttle run (s); hang (quantity of 
times); sit-ups (quantity of times); inclinations of a trunk (cm); long jump from the spot $(\mathrm{cm})$. Results of control tests were expressed in metric units.

Statistical analysis

It was applied Statistica 7.0 programs (Stat Soft inc., USA). It was determined the arithmetic average mean of indicators (M), a standard deviation (SD). The significance of distinctions of average means of independent samples was estimated by parametrical methods by means of Student t-test. The differences between means of indicators are considered statistically significant at the level $\mathrm{p}<0.05$.

\section{Results}

Distribution of all students according to the indicator mean of BMI is presented in fig. 1, 2. Students of group " $U$ " with underweight didn't participate in further research.

The males have overweight in 1.7 times more often, and have obesity in 2.5 times more often than females, who have underweight in $36,1 \%$ times more often (in 1 , 8 times).

The females of group "OV" and "OB" have increase in indicator mean of BMI (in 15.8\%; in 29.8\%) in comparison with group " $\mathrm{N}$ ". The majority of physiometrics are higher in students with a normal weight (tab. 1), than in females with overweight and obesity $(\mathrm{p}<0.05)$.

The females of group "OV" and "OB" (tab. 2) had lower indicators means of all motor tests (except test "20 m run"), than females of group " $\mathrm{N}$ " $(\mathrm{p}<0.05)$. It was determined the difference in quantitative content of muscular (MM) and fat (FM) body mass in females of different groups (fig. 3).

The females of group "OV" had: the content of muscle mass in component structure of a body in $9.7 \%$ less and fat mass in $12.2 \%$ more, than females of group " $\mathrm{N}$ ". Females of group "OB" had: less content of muscle mass in component structure of body in $22.1 \%$ and more in $25.2 \%$ of fat mass, than females of group " $N$ ".

The males of groups "OV" and "OB" had higher means of BMI (in $16.58 \%$; in $30.7 \%$ ) in comparison with group "N". The majority of cardiovascular system indicators and all indexes in males of group " $\mathrm{N}$ " (tab. 3) were higher, than in males with overweight and obesity $(\mathrm{p}<0.05)$.

The males of groups "OV" and "OB" had the lowest indicators in five of seven motor tests (shuttle run, $100 \mathrm{~m}$ run, $1000 \mathrm{~m}$ run, pull-ups, long jump), in comparison with males of group " $\mathrm{N}$ ".

According to the results of a research was determined the difference in quantitative content of muscular (MM) and fat (FM) body mass in males of different groups (fig. 4).

The males of group "OV" had the content of muscle mass in $13,7 \%$ less and the fat mass in $17.1 \%$ more, than in males of group "N". The males of group "OB" had

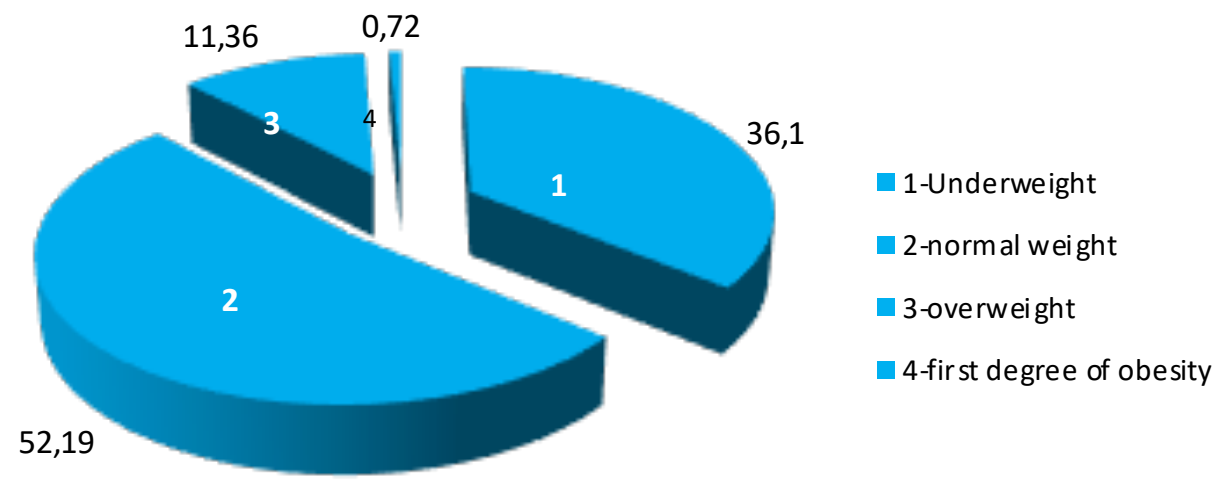

Fig. 1. Distribution of females according to BMI (in \% to quantity of examined persons)

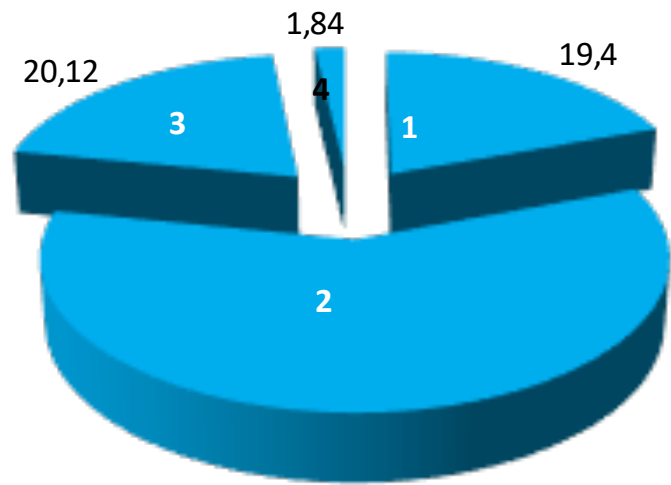

58,71

\author{
1-Underweight \\ n-normal weight \\ 3-overweight \\ 4-first degree of obesity
}

Fig. 2. Distribution of males according to BMI (in \% to quantity of examined persons) 
Table 1. The morphofunctional characteristics of females with different means of BMI (M $\pm S D)$

\begin{tabular}{|c|c|c|c|}
\hline Indicators & $\begin{array}{l}\text { Group «N» } \\
(n=1011)\end{array}$ & $\begin{array}{l}\text { Group «OV» } \\
(n=220)\end{array}$ & $\begin{array}{l}\text { Group «OB» } \\
(n=14)\end{array}$ \\
\hline \multicolumn{4}{|l|}{ Somatometrics } \\
\hline Body height, cm & $164.7 \pm 0.17$ & $165.0 \pm 0.34$ & $156.7 \pm 1.54 * \#$ \\
\hline Body weight, kg & $56.9 \pm 0.14$ & $68.5 \pm 0.35^{*}$ & $73.4 \pm 1.74 * \#$ \\
\hline Chest circumference, $\mathrm{cm}$ & $87.3 \pm 0.12$ & $90.8 \pm 0.33^{*}$ & $96.8 \pm 1.93 * \#$ \\
\hline \multicolumn{4}{|l|}{ Physiometrics } \\
\hline $\mathrm{VCL}, \mathrm{ml}$ & $2701.0 \pm 14.0$ & $2712.0 \pm 30.0$ & $2691.0 \pm 123.0$ \\
\hline $\mathrm{RHR}, \mathrm{b} / 10 \mathrm{~s}$ & $11.71 \pm 0.02$ & $11.76 \pm 0.05$ & $12.07 \pm 0.13 * \#$ \\
\hline HR after 20 squats in $30 \mathrm{~s}, \mathrm{~b} / 10 \mathrm{~s}$ & $21.0 \pm 0.08$ & $21.1 \pm 0.18$ & $19.78 \pm 0.42$ \\
\hline HR recovery time after 20 squats in $30 \mathrm{~s}$, min & $1.42 \pm 0.01$ & $1.48 \pm 0.04$ & $2.14 \pm 0.18^{*} \#$ \\
\hline ABPs, $\mathrm{mmHg}$ & $105.6 \pm 0.30$ & $109.7 \pm 0.79 *$ & $116.0 \pm 1.92 * \#$ \\
\hline $\mathrm{ABPd}, \mathrm{mmHg}$ & $69.12 \pm 0.17$ & $69.4 \pm 0.39$ & $70.2 \pm 0.39$ \\
\hline Dynamometry of left hand, kg & $23.1 \pm 0.17$ & $23.2 \pm 0.41$ & $22.7 \pm 0.86$ \\
\hline Dynamometry of right hand, $\mathrm{kg}$ & $24.1 \pm 0.17$ & $23.5 \pm 0.44$ & $23.1 \pm 1.64$ \\
\hline \multicolumn{4}{|l|}{ Indexes } \\
\hline Body weight index, kg/m² & $21.2 \pm 0.13$ & $25.2 \pm 0.43^{*}$ & $30.2 \pm 1.88 * \#$ \\
\hline Robinson index, c.u. & $74.13 \pm 0.21$ & $77.4 \pm 0.40^{*}$ & $84.0 \pm 0.65 * \#$ \\
\hline Vital index, ml/kg & $47.4 \pm 0.11$ & $39.5 \pm 0.37^{*}$ & $36.6 \pm 2.14 *$ \\
\hline Strong index of left hand,\% & $40.5 \pm 0.09$ & $33.8 \pm 0.27^{*}$ & $30.9 \pm 1.70 *$ \\
\hline Strong index of right hand,\% & $42.3 \pm 0.10$ & $34.3 \pm 0.29 *$ & $31.4 \pm 1.96^{*}$ \\
\hline
\end{tabular}

Note -* significant differences between indicators of groups: "N", “OV" and "OB" $(P<0,05)$; - \# significant differences between indicators of groups "OV" and "OB" $(\mathrm{P}<0,05)$.

Table 2. the results of motor tests of females with different means of $B M I(M \pm S D)$

\begin{tabular}{llll}
\hline Tests & $\begin{array}{l}\text { Group «N" } \\
(\mathbf{n = 1 0 1 1 )}\end{array}$ & $\begin{array}{l}\text { Group «OV» } \\
(\mathbf{n = 2 2 0 )}\end{array}$ & $\begin{array}{l}\text { Group «OB» } \\
(\mathbf{n}=\mathbf{1 4})\end{array}$ \\
\hline 20 m run, s & $3.98 \pm 0.05$ & $3.94 \pm 0.09$ & $3.93 \pm 0.34$ \\
$10 \times 5$ m shuttle run, s & $21.25 \pm 0.06$ & $22.43 \pm 0.15^{*}$ & $23.55 \pm 0.39^{* \#}$ \\
5 min run, m & $890.2 \pm 6.33$ & $820.0 \pm 14.1^{*}$ & $762.7 \pm 22.67^{* \#}$ \\
Hang, s & $9.37 \pm 0.16$ & $8.35 \pm 0.36^{*}$ & $5.19 \pm 1.36^{*} \#$ \\
Sit-ups, reps & $23.5 \pm 0.22$ & $21.3 \pm 0.37^{*}$ & $16.3 \pm 0.72^{* \#}$ \\
Trunk bending, cm & $15.38 \pm 0.21$ & $14.8 \pm 0.38$ & $11.0 \pm 0.9^{* \#}$ \\
Long jump from the spot, cm & $150.93 \pm 0.52$ & $143.0 \pm 1.22^{*}$ & $131.0 \pm 4.51$ ? \# \\
Integral criterion (points) & $3.02 \pm 0.01$ & $2.86 \pm 0.03^{*}$ & $2.18 \pm 0.09^{* \#}$ \\
\hline
\end{tabular}

Note -* significant differences between indicators of groups "N", “OV" and "OB" $(P<0,05)$; - \# significant differences between indicators of groups "OV" and "OB" $(P<0,05)$.

Table 3. The morphofunctional characteristics of males with different means of $B M I(M \pm S D)$

\begin{tabular}{|c|c|c|c|}
\hline Indicators & Group «N» $(n=765)$ & $\begin{array}{l}\text { Group «OV» } \\
(n=262)\end{array}$ & $\begin{array}{l}\text { Group «OB» } \\
(n=24)\end{array}$ \\
\hline 1 & 2 & 3 & 4 \\
\hline \multicolumn{4}{|l|}{ Somatometrics } \\
\hline Body height, cm & $177.9 \pm 0.22$ & $177.3 \pm 0.38$ & $174.5 \pm 2.08$ \\
\hline Body weight, kg & $67.0 \pm 0.19$ & $79.9 \pm 0.39 *$ & $93.2 \pm 2.0 * \#$ \\
\hline Chest circumference, $\mathrm{cm}$ & $93.81 \pm 0.19$ & $98.54 \pm 0.36^{*}$ & $106.2 \pm 1.9 * \#$ \\
\hline \multicolumn{4}{|l|}{ Physiometrics } \\
\hline VCL, ml & $4180.0 \pm 19.3$ & $4207.5 \pm 32.2$ & $4200.0 \pm 130.0$ \\
\hline RHR, b/10 s & $12.04 \pm 0.03$ & $12.19 \pm 0.05^{*}$ & $12.57 \pm 0.25^{*}$ \\
\hline
\end{tabular}


Continuation of table 3

\begin{tabular}{llll}
\hline $\mathbf{1}$ & $\mathbf{2}$ & $\mathbf{3}$ & $\mathbf{4}$ \\
\hline HR after 20 squats in $30 \mathrm{~s}, \mathrm{~b} / 10 \mathrm{~s}$ & $19.02 \pm 0.05$ & $19.18 \pm 0.10$ & $19.34 \pm 0.49$ \\
HR recovery time after 20 squats in $30 \mathrm{~s}, \mathrm{~min}$ & $0.93 \pm 0.01$ & $1.04 \pm 0.01^{*}$ & $1.89 \pm 0.06^{*} \#$ \\
ABPs, $\mathrm{mmHg}$ & $114.0 \pm 0.27$ & $115.5 \pm 0.40$ & $116.8 \pm 1.5$ \\
ABPd, $\mathrm{mmHg}$ & $72.9 \pm 0.24$ & $74.0 \pm 0.41$ & $74.5 \pm 1.12$ \\
Dynamometry of left hand, $\mathrm{kg}$ & $43.0 \pm 0.12$ & $43.8 \pm 0.21$ & $42.8 \pm 1.34$ \\
Dynamometry of right hand, kg & $44.9 \pm 0.23$ & $44.8 \pm 0.28$ & $43.3 \pm 1.45$ \\
Indexes & & & $30.6 \pm 0.75^{* \#}$ \\
Body weight index, kg/m ${ }^{2}$ & $21.2 \pm 0.06$ & $25.4 \pm 0.18^{*}$ & $88.8 \pm 1.32^{* \#}$ \\
Robinson index, c.u. & $82.3 \pm 0.27$ & $84.4 \pm 0.64^{*}$ & $45.1 \pm 1.56^{* \#}$ \\
Vital index, $\mathrm{ml} / \mathrm{kg}$ & $62.3 \pm 0.18$ & $52.6 \pm 0.32^{*}$ & $45.9 \pm 1.58^{* \#}$ \\
Strong index of left hand,\% & $64.2 \pm 0.19$ & $54.8 \pm 0.41^{*}$ & $46.4 \pm 1.62^{* \#}$ \\
Strong index of right hand,\% & $67.8 \pm 0.20$ & $56.1 \pm 0.44^{*}$ & \\
\hline
\end{tabular}

Note -* significant differences between indicators of groups: "N", “OV" and "OB" $(P<0,05)$; - \# significant differences between indicators of groups "OV" and "OB" $(P<0,05)$.

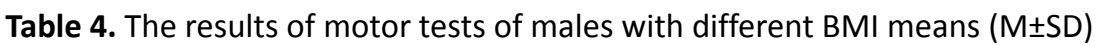

\begin{tabular}{llll}
\hline Tests & Group «N» $(\mathbf{n = 7 6 5 )}$ & Group «OV» $\left(\mathbf{n = 2 6 2 )} \begin{array}{l}\text { Group «OB» } \\
(\mathbf{n = 2 4 )}\end{array}\right.$ \\
\hline $10 \times 5$ m shuttle run, s & $16.04 \pm 0.04$ & $16.34 \pm 0.08^{*}$ & $16.58 \pm 0.28$ ? \\
100 m run, s & $13.84 \pm 0.35$ & $15.23 \pm 0.08^{*}$ & $16.6 \pm 0.28^{* \#}$ \\
1000 m run, min & $3: 51.85 \pm 0: 00.8$ & $3: 56.65 \pm 0: 01.5$ ? & $4: 05.69 \pm 0: 06.7^{* \#}$ \\
Pull-ups, reps & $11.08 \pm 0.15$ & $9.92 \pm 0.27^{*}$ & $7.34 \pm 0.88$ ? \\
Sit-ups, reps & $29.3 \pm 0.20$ & $29.5 \pm 0.28$ & $29.1 \pm 0.76$ \\
Forward bend, cm & $16.9 \pm 0.26$ & $17.12 \pm 0.43$ & $15.2 \pm 1.59$ \\
Long jump, cm & $238.5 \pm 0.58$ & $232.8 \pm 1.07^{*}$ & $216.6 \pm 3.88^{* \#}$ \\
Integral criterion (points) & $3.23 \pm 0.01$ & $2.92 \pm 0.02^{*}$ & $2.71 \pm 0.07^{* \#}$ \\
\hline
\end{tabular}

Note -* significant differences between indicators of groups: "N", "OV" and "OB" $(P<0,05)$; - \# significant differences between indicators of groups "OV" and “OB" $(P<0,05)$.

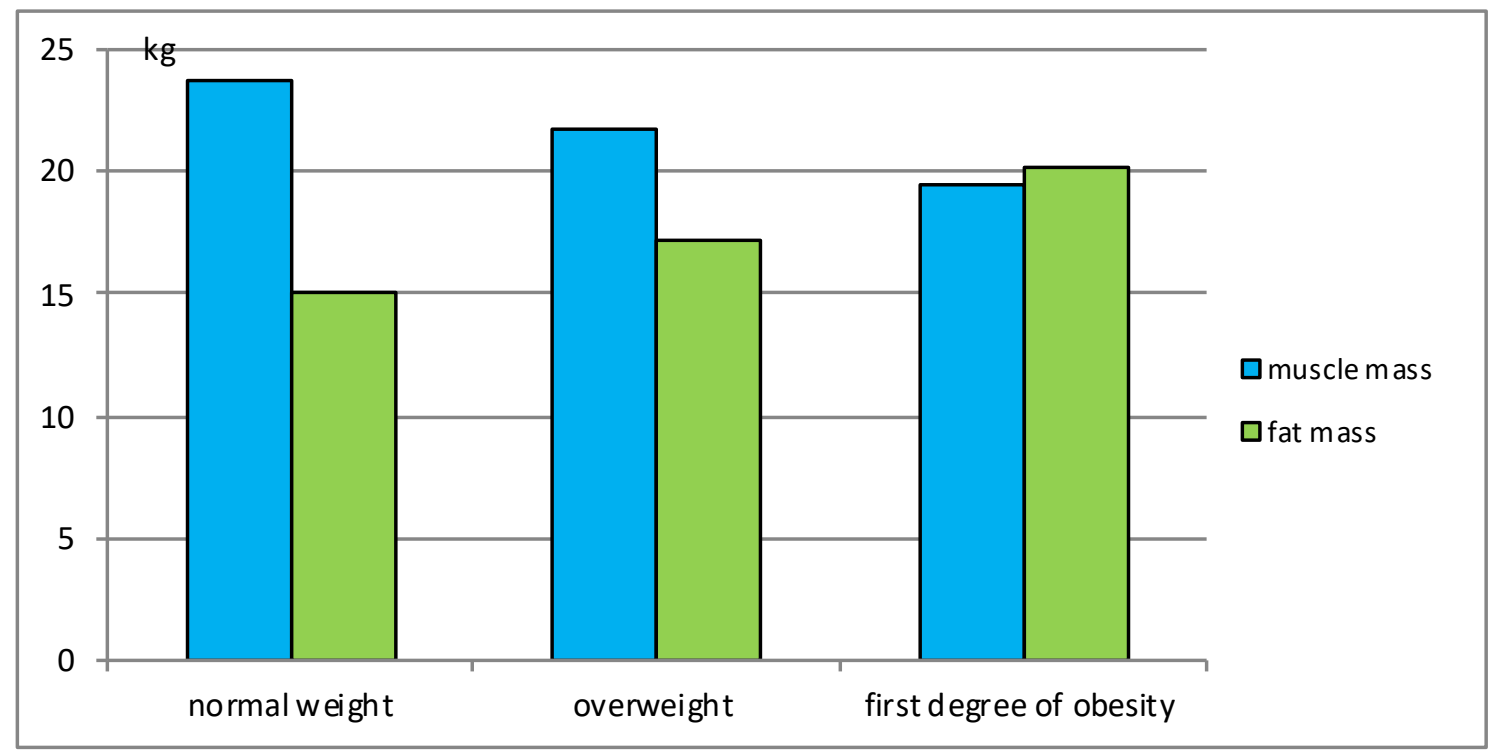

Fig. 3. Muscular and fat content of body $(\mathrm{kg})$ of females with different BMI means 


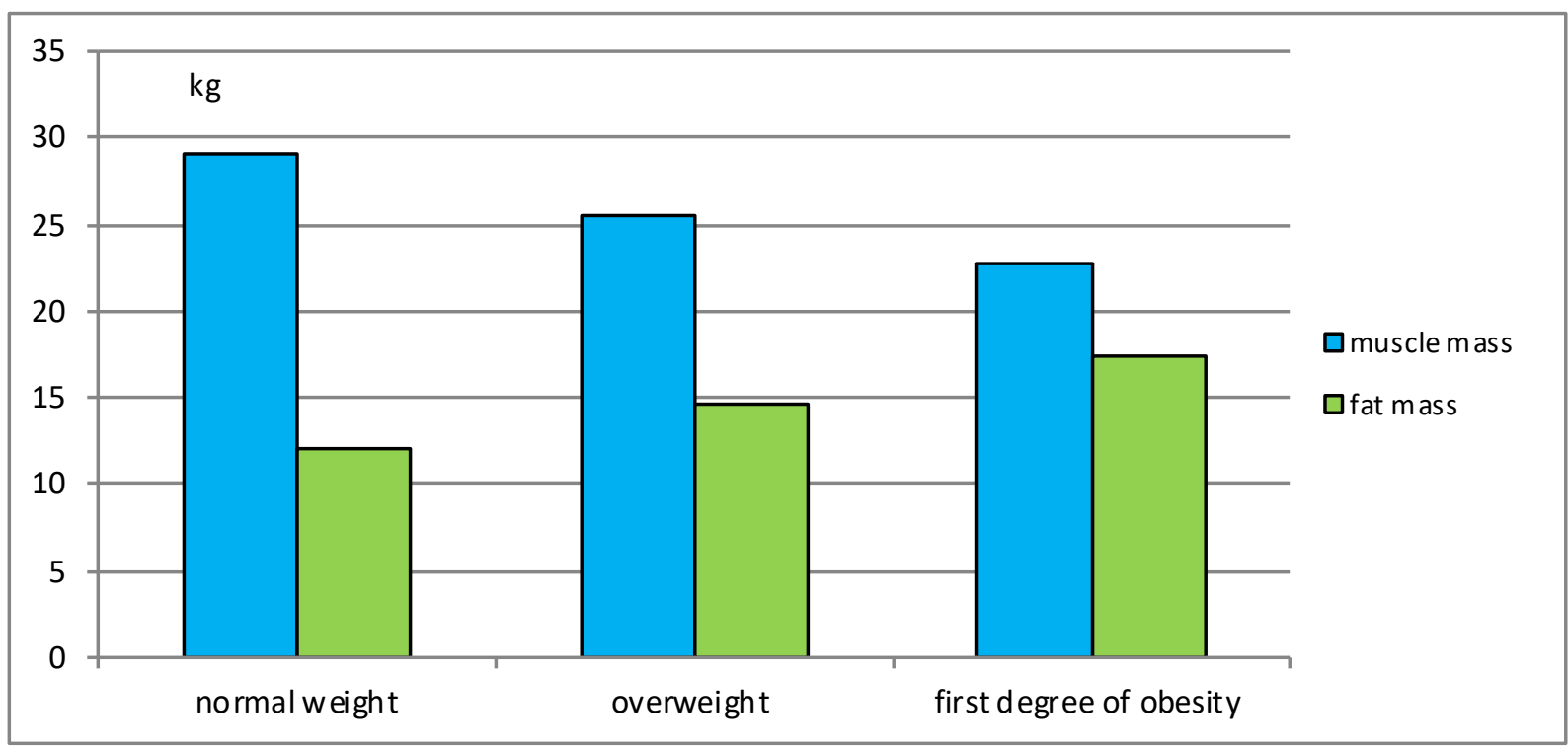

Fig. 4. Muscular and fat structure of body $(\mathrm{kg})$ of males with different BMI means

the content of muscle mass in $27.6 \%$ less and fat mass in $30.4 \%$ more, than in group "N".

\section{Discussion}

The overweight and obesity are risk factors for noninfectious diseases of human [33]. One of the reasons for such phenomenon is the inactive way of lifestyle of population [64, 65]. On a global scale, the physical activities are the fourth important factor, decreasing the risk of human death [25]. In Russian Federation, about $30 \%$ of the population suffers from overweight [51]. According to our data males from Baikal region have overweight and obesity more often than females. It will be coordinated with results of researches in other regions of Russia [66, 67]. Females are more motivated on asthenic constitution [68]. It is confirmed by the questioning of Romania students concerning the index of dissatisfaction with a constitution on The Beck Depression Inventory [69]. More than $41 \%$ of female students answered that it is possible to improve a body figure [69] by physical training and adhere healthy lifestyle. The analysis of results of the conducted research demonstrated the essential difference between anthropometrical and physiometric indicators in females and at the males with different BMI.

Anthropometrical indicators (body weight, CC) and physiometric characteristics $\left[\mathrm{HR}_{\text {rest }}\right.$ and time of $\mathrm{HR}$ recovery after 20 squats; systolic arterial blood pressure (except males); Robinson index; vital and strong indexes] were better in group " $N$ ", than all students in groups "OV" and "OB" $(p<0.05)$. The lowest results of anthropometry and physiometry are revealed in males and females of group "OB" $(p<0.05)$. The similar dependence of anthropometrical indicators of the person and overweight and obesity is noted by others researches $[49,70]$.

It is determined that the females of group "OV" and "OB" have high means of indicators of systolic arterial blood pressure, in comparison with females of group "N". Results of our researches are confirmed by scientific works in which were defined the interrelation between overweight, obesity and arterial hypertension [32, 33]. It can lead to heart attacks and brain strokes.

According to our data students with overweight and obesity have significant low indicators of cardiovascular system condition $\left(\mathrm{HR}_{\text {rest }}\right.$ and HR recovery time after 20 squats), than students with normal body weight ( $p<0.05$ ). It is confirmed with results of research devoted to the cardiorespiratory system in women of the first mature age in Ukraine [71].

The indicator of cardiovascular system activity is Robinson index. According to our data males and females of group " $N$ " have a low mean of this index. The students of group "OV" and "OB" have significantly high Robinson index than students of groups "N". It demonstrates the decrease in activity of cardiovascular system in students with overweight and obesity. However, our data differ from results of examination of females with overweight in the Tyva Republic (Russia) [72]. Authors determined low means of Robinson index and great reserve opportunities of an organism for physical activity.

According to our data, the physical fitness of females and males with overweight and obesity is much lower in comparison with results of testing of students with a normal weight. It is confirmed by researches of other authors $[45,73]$. It was determined (tab. 2, 4) that females with overweight have significantly low results in five of seven motor tests. The males with overweight and obesity have low results in five tests $(\mathrm{p}<0.05)$. In comparison with students with normal weight, males and females (groups "OV" and "OB") have the decrease in results in motor tests. It is confirmed by the integrated criterion of motor qualities tests (fig. 5).

The mean grade of integrated criterion of physical fitness (fig. 5) of females of group "OV" (with overweight) and females of group "OB" (with obesity of the I degree) was $2.86 \pm 0.03$ and $2.18 \pm 0.09$ points respectively. It was in $5,3 \%$ and $27.8 \%$ lower than mean grade of female 


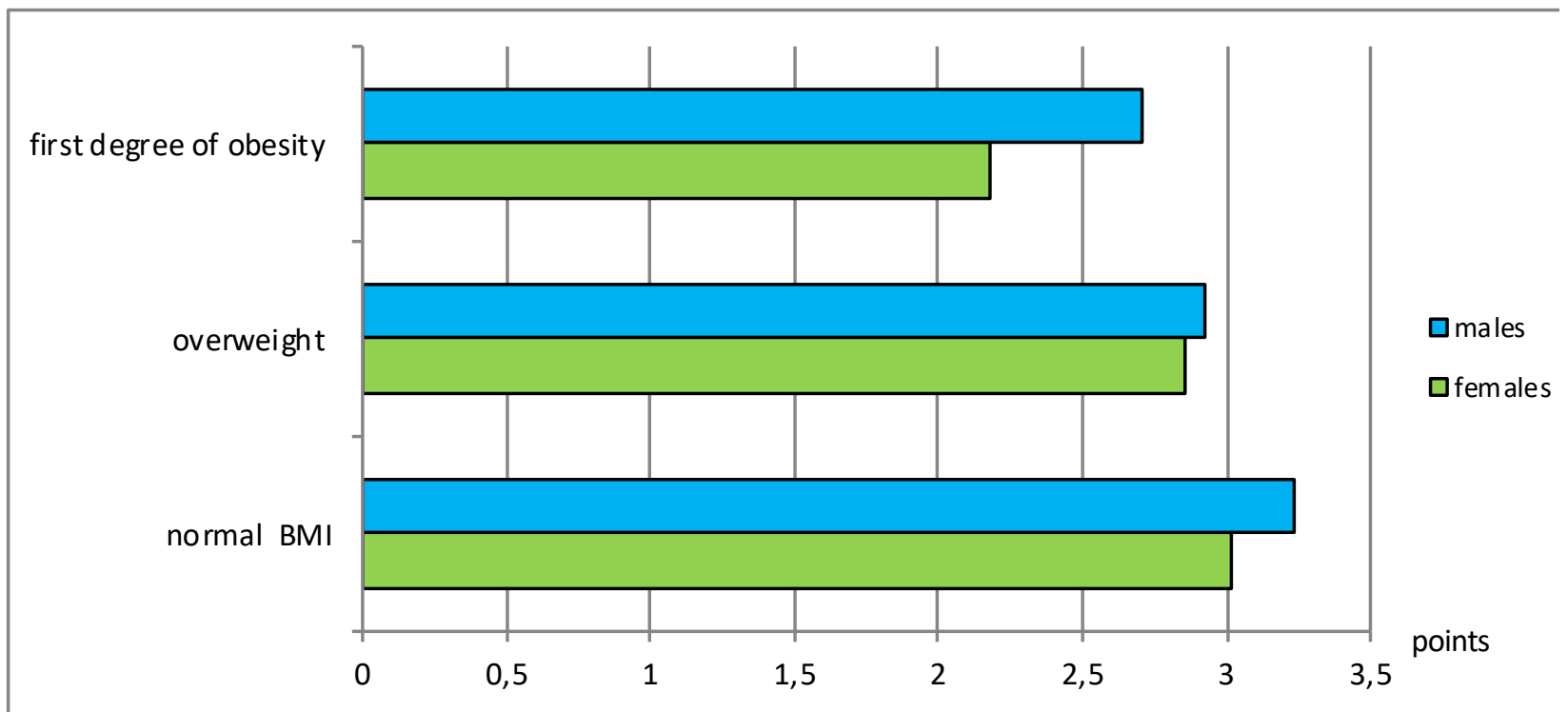

Fig. 5. Integrated criterion of physical fitness level of females and males with different BMI means.

students with a normal weight $(\mathrm{p}<0.05)$. The mean grade of integrated criterion of physical fitness (fig. 5) of males of group "OV" (with overweight) and males of group "OB" (with first-degree obesity) was $2.92 \pm 0.02$ and $2.81 \pm 0.07$ points respectively. It was in $9.6 \%$ and $16.1 \%$ is lower than a mean grade of students with a normal weight $(\mathrm{p}<0.05)$. Low characteristics of motor qualities of males and females with overweight and obesity are caused by: weak heart function, insufficient content of muscular tissue, overage of fat tissue in component structure of body. The obtained data (fig. 3,4 ) confirm the low content of muscle mass and considerable overage of fat mass in component structure of students bodies (with overweight and obesity) in comparison with students of group "N" $(p<0.05)$. These data conform with researches of others authors $[73,74]$ and our previous researches ${ }^{75}$.

Overweight doesn't allow to develop speed and flexibility of students. The lack of a muscular component in all students' bodies (group "OV" and "OB") decrease in results of motor tests for manifestation of strength, high-speed and general endurance. Characteristics of these motor qualities were lower, than in students with normal weight (group " $\mathrm{N}$ ", $\mathrm{p}<0.05$ ).

We agree with ideas of other authors [76] concerning decrease in body weight and improvement of motor abilities of the person. It is recommended to apply moderated and long (more than $30 \mathrm{~min}$ ) aerobic motor exercises for decrease in fat component in a body and improvement of cardiovascular system activity. It is necessary to apply high-intensity physical activities which allow to intensify synthesis of protein in organism [77] for increase in muscle mass of a body.

\section{Conclusion}

1. Female and male of 17-21-year-olds with overweight and obesity have lower anthropometrical and functional characteristics of organism and motor qualities, than students with a normal weight. Such students have less content of muscle mass in component structure of body, than students with normal weight. Also the content of fat mass is more, than in students with normal weight $(p<0.05)$. It is determined the dependence between the quantity of body fat mass of males and females with the level of their physical fitness.

2. The obtained data concerning features and interrelation of anthropometrical, functional characteristics and motor qualities of females and males (with different body weight) allow to correct educational process of physical training of youth. The basis of such process is made by physical exercises which promote decrease in content of fat mass and to increase in muscle mass in component structure of students' bodies.

\section{Conflict of interest}

The authors declare no conflict of interest. 


\section{References}

1. Obesity and overweight. Fact sheet, WHO, [Internet] 2017 Oct 18 [cited 2018 Apr 28]. Available from: http://www.who.

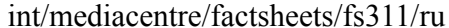

2. Martinchik AN, Baturin AK, Peskova EV, Gender and age characteristics and the trends in prevalence of obesity in the adult population in Russia during the 1994-2012 period. Voprosy pitaniia, 2015; 3:50. (in Russian)

3. Global Strategy on Diet, Physical Activity and Health, WHO, [Internet] 2004 May [cited 2018 Apr 28]. Available from: http://www.who.int/dietphysicalactivity/strategy/eb11344/ru

4. Heeb J-L. Changes in the prevalence of overweight and obesity: some evidence from the Swiss Health Surveys 1992/93 and 2002. The European Journal of Public Health. 2011;1;21(4):407-13. https://doi.org/10.1093/eurpub/ckp138

5. Popkin BM. Recent dynamics suggest selected countries catching up to US obesity. The American Journal of Clinical Nutrition. 2009;91(1):284S-288S. https://doi.org/10.3945/ajen.2009.28473C

6. Almond D, Lee A, Schwartz AE. Impacts of classifying New York City students as overweight. Proceedings of the National Academy of Sciences. 2016;113(13):3488-91. https://doi.org/10.1073/pnas.1518443113

7. Bloch KV, Klein CH, Szklo M, Kuschnir MCC, Abreu G de A, Barufaldi LA, et al. ERICA: prevalences of hypertension and obesity in Brazilian adolescents. Revista de Saúde Pública [Internet]. 2016 [cited 2019 Feb 22];50(suppl 1). Available from: http://www.scielo.br/scielo.php?script=sci arttext\&pid=S0034-89102016000200306\&lng=en\&tlng=en https://doi.org/10.1590/s01518-8787.2016050006685

8. Kann L, McManus T, Harris WA, Shanklin SL, Flint KH, Hawkins J, et al. Youth Risk Behavior Surveillance. United States, 2015. MMWR Surveillance Summaries. 201610;65(6):1-174. https://doi.org/10.15585/mmwr.ss6506a1

9. Lawlis T, Knox M, Jamieson M. School canteens: A systematic review of the policy, perceptions and use from an Australian perspective: School canteens: Policy, perceptions and use. Nutrition \& Dietetics. 2016;73(4):389-98. https://doi.org/10.1111/1747-0080.12279

10.Poobalan A, Aucott L. Obesity Among Young Adults in Developing Countries: A Systematic Overview. Current Obesity Reports. 2016;5(1):2-13.https://doi.org/10.1007/s13679-016-0187-x

11.Zhang Y, Wang Z, Zhao J, Chu Z. Trends in overweight and obesity among rural children and adolescents from 1985 to 2014 in Shandong, China. European Journal of Preventive Cardiology. 2016;23(12):1314-20. https://doi.org/10.1177/2047487316643830

12.Azizi-Soleiman F, Motlagh ME, Qorbani M, Heshmat R, Ardalan G, Mansourian M, et al. Dietary Habits and Health Related Behaviors in Iranian Children and Adolescents: The CASPIAN-IV Study. International Journal of PediatricsMashhad. 2016;4(7):2087-2097.

13.Kowalkowska J, Poínhos R, Franchini B, Afonso C, Correia $\mathrm{F}$, Pinhão S, et al. General and abdominal adiposity in a representative sample of Portuguese adults: dependency of measures and socio-demographic factors' influence. British Journal of Nutrition. 2016;115(01):185-92. https://doi.org/10.1017/S0007114515004055

14.Musaiger AO, Al-Khalifa F, Al-Mannai M. Obesity, unhealthy dietary habits and sedentary behaviors among university students in Sudan: growing risks for chronic diseases in a poor country. Environmental
Health and Preventive Medicine. 2016;21(4):224-30. https://doi.org/10.1007/s12199-016-0515-5

15.Patsopoulou A, Tsimtsiou Z, Katsioulis A, Rachiotis G, Malissiova E, Hadjichristodoulou C. Prevalence and Risk Factors of Overweight and Obesity among Adolescents and Their Parents in Central Greece (FETA Project). International Journal of Environmental Research and Public Health. 2015;13(1):83. https://doi.org/10.3390/ijerph13010083

16.Rivera-Soto WT, Rodriguez-Figueroa L. Is Waist-to-Height Ratio a Better Obesity Risk-Factor Indicator for Puerto Rican Children than is BMI or Waist Circumference? Puerto Rico Health Sciences Journal. 2016;35(1):20-25.

17.Shih S-F, Liu C-H, Liao L-L, Osborne RH. Health literacy and the determinants of obesity: a population-based survey of sixth grade school children in Taiwan. BMC Public Health [Internet]. 2016 Dec [cited 2019 Feb 22];16(1). Available from: http://www.biomedcentral.com/1471-2458/16/280 https://doi.org/10.1186/s12889-016-2879-2

18.Ville AP, Heyman MB, Medrano R, Wojcicki JM. Early Antibiotic Exposure and Risk of Childhood Obesity in Latinos. Childhood Obesity. 2017;13(3):231-5. https://doi.org/10.1089/chi.2016.0235

19. Wakayo T, Whiting S, Belachew T. Vitamin D Deficiency is Associated with Overweight and/or Obesity among Schoolchildren in Central Ethiopia. A Cross-Sectional Study. Nutrients. 2016;8(4):190. https://doi.org/10.3390/nu8040190

20.Wu X, Kirk SFL, Ohinmaa A, Veugelers P. Health behaviours, body weight and self-esteem among grade five students in Canada. SpringerPlus [Internet]. 2016 Dec [cited 2019 Feb 22];5(1). Available from: http://springerplus. springeropen.com/articles/10.1186/s40064-016-2744-x https://doi.org/10.1186/s40064-016-2744-x

21.Marfina V, Salivon I, Dynamics of Distribution of the Body Mass Index of Schoolchildren in the Republic of Belarus. Coll Antropol, 2017;41(2): 1-10.

22.Tutkuviene J, Misiute A, Strupaite I, Paulikaite G, Pavlovskaja E. Body Image Issues in Lithuanian Magazines Aimed for Children and Adolescents in Relation to Body Mass Index and Body Size Perception of 16-19 Y. Old Girls During the Last 15 Years. Coll Antropol, 2017;41(1): 19-26.

23.Ipatov PV, Popovich MV. The interdepartmental strategy of formation of a healthy lifestyle of the population, prevention and control of noninfectious diseases till 2025. Moscow; 2016. (in Russian)

24.Sadovskaia OA, Sitnikova EM, Shibanova MIU. Prospects of improving university students' health condition based on nutrition optimization. Medicina v Kuzbasse, 2013;3:58-64. (in Russian)

25.Goldaeva PR, Pavlenko OA. The incidence of obesity among students of Tomsk. Sovremennye problemy nauki $i$ obrazovaniia, 2016;6(6): 1-10. (in Russian)

26.Vartanova OT, Evtushenko AV, Nor-Arevian KA, Sidorova EN. Some constitutional features of residents in the Rostov region. Astrakhanskij medicinskij zhurnal, 2013;1:48-55. (in Russian)

27.Callagova RB, Appak GA, Komissarova EN. Individual and typological features of 17-18-year-olds students with various diseases. Russian scientific and practical conference devoted to the 80 anniversary of department of sports medicine and technologies of health of NSU of P.F. Lesgaft and the 175 anniversary since the birth of P.F. Lesgaft, on December 2728, 2012. Sankt Petersburg; 2012. P. 64-70. (in Russian)

28.Musikhina EA. Risk assesment of Irkutsk region territory, Uspekhi sovremennogo estestvoznaniia, 2012;2:26-32. (in 
Russian)

29.Kolokoltsev MM, Lumpova OM. Somatotypological characteristics of young male population in the trans-Baikal region. Vestnik IrGTU, 2012;2(61):226-232. (in Russian)

30.Obesity: preventing and managing the global epidemic. Report of a WHO consultation. World Health Organ Tech Rep Ser 894(i-xii). 2000.

31.Yusuf S, Hawken S, Ônpuu S, Dans T, Avezum A, Lanas F, et al. Effect of potentially modifiable risk factors associated with myocardial infarction in 52 countries (the INTERHEART study): casecontrol study. The Lancet. 2004;364(9438):937-52. https://doi.org/10.1016/S0140-6736(04)17018-9

32.Banes CJ. Firefighters' Cardiovascular Risk Behaviors: Effective Interventions and Cultural Congruence. Workplace Health \& Safety. 2014;62(1):27-34. https://doi.org/10.1177/216507991406200105

33.Arkhangel'skaia AN, Burdiukova EV, Ivkina MV, Lastoveckij AG, Kudencova SN, Stulina DD, Gurevich KG. Obesity as a risk factor for chronic noncommunicable diseases in persons of dangerous occupations. Sovremennye problemy nauki $i$ obrazovaniia, 2015;5:10-16. (in Russian)

34.Docenko VA, Kononenko IA, Mosijchuk LV. Monitoring the nutritional status of the residents of St. Petersburg. Voprosy pitaniia, 2015;3:58-64. (in Russian)

35.Choudhary AK, Donnelly LF, Racadio JM, Strife JL. Diseases Associated with Childhood Obesity. American Journal of Roentgenology. 2007 Apr;188(4):1118-30. https://doi.org/10.2214/AJR.06.0651

36.Caballero B. A Nutrition Paradox - Underweight and Obesity in Developing Countries. New England Journal of Medicine. 2005 Apr 14;352(15):1514-6. https://doi.org/10.1056/NEJMp048310

37.Physical activity Fact sheet. WHO. WHO, [Internet] 2018 Feb 18 [Updated February 2018, cited 2018 Apr 28]. Available from: http://www.who.int/news-room/fact-sheets/ detail/physical-activity

38.Noncommunicable diseases and mental health. Global Action Plan for the Prevention and Control of NCDs 2013-2020. WHO, [Internet] 2018 Apr 28 [cited 2018 Apr 28]. Available from: http://www.who.int/nmh/events/ncd_action_plan/en/

39.Padua E, Campoli F, Manzi V, Panzarino M, Lombardo $\mathrm{M}$, Melchiorri $\mathrm{G}$, et al. Water versus land-based exercises as physical training programs in elderly. Journal of Sports Medicine and Physical Fitness. 2018;58(6):802-809. https://doi.org/10.23736/s0022-4707.17.07307-8

40. Vetter RE, Yu H, Foose AK. Effects of moderators on physical training programs: a bayesian approach. Journal of Strength and Conditioning Research. 2017;31(7):1868-1878. https://doi.org/10.1519/jsc.0000000000001585

41.Merino-Orozco A, Arraiz-Perez A, Sabiron-Sierra F. The child's emotional management in school competition: underseven football. Infancia Y Aprendizaje. 2018;41(4):794-823. https://doi.org/10.1080/02103702.2018.1504862

42.Ridder MAM, Koning M, Visscher TLS, Hirasing RA, Seidell JC, Renders CM. Energy Balance-Related Behavior and Anthropometric Measures Among Adolescents Across Three Educational Levels: A Cross-Sectional Study in Dutch Schools. Health Education \& Behavior. 2018;45(3):349-358. https://doi.org/10.1177/1090198117715666

43. Mihrshahi S, Drayton BA, Bauman AE, Hardy LL. Associations between childhood overweight, obesity, abdominal obesity and obesogenic behaviors and practices in Australian homes. Bmc Public Health. 2017;18. https://doi.org/10.1186/s12889-017-4595-y
44.Jekauc D, Wagner MO, Herrmann C, Hegazy K, Woll A. Does Physical Self-Concept Mediate the Relationship between Motor Abilities and Physical Activity in Adolescents and Young Adults? Plos One. 2017;12(1). https://doi.org/10.1371/journal.pone.0168539

45.Bubnenkova OM. Somatic and physical condition of children with excess body weight somatic and physical condition of children with excess body weight. Uchenye zapiski universiteta im. P.F. Lesgafta, 2015;11(129): 64-71. (in Russian)

46.Taiutina TV, Lysenko AV, Taiutina TV, Lysenko DS, Nedoruba EA. The role of health-improving technologies in maintaining optimal body weight in women of different age. Sovremennye problemy nauki i obrazovaniia, 2014;3:25-32. (in Russian)

47.Vasilec VV, Kostiuchenko VF, Vrublevskij EP. Comparative analysis of changes of componential structure of the body under the influence of training loading of health-improving character. Uchenye zapiski universiteta im. P.F. Lesgafta, 2015;1(119:48-55. (in Russian)

48.Daskalopoulou C, Stubbs B, Kralj C, Koukounari A, Prince M, Prina AM. Physical activity and healthy ageing: A systematic review and meta-analysis of longitudinal cohort studies. Ageing Research Reviews. 2017;38:6-17. https://doi.org/10.1016/j.arr.2017.06.003

49.Kim TK, Sokolova VS, Dias Luk'ianova MI. The program normalization of body weight in girls of 14-15 years oldoverweight using modern methods of control of active and passive components of body composition. Sovremennye problemy nauki i obrazovaniia, 2017;5:20-27. (in Russian)

50.Carvalho VS, Guerrero E, Chambel MJ. Emotional intelligence and health students' well-being: A twowave study with students of medicine, physiotherapy and nursing. Nurse Education Today. 2018;63:35-42. https://doi.org/10.1016/j.nedt.2018.01.010

51.Malkina-Pykh IG. Psychological correction of the eating behavior disorders and obesity by the methods of rhythmic movement health improving physical culture. Uchenye zapiski universiteta im. P.F. Lesgafta, 2011;13(73):124-130. (in Russian)

52.Vilaca-Alves J, Regado A, Marinho D, Neves EB, Rosa C, Saavedra F, et al. Sequence effects of combined resistance exercises with step choreography in the same session in women's oxygen uptake during and postexercise. Clinical Physiology and Functional Imaging. 2018;38(1):63-68. https://doi.org/10.1111/cpf.12382

53.Faude O, Hecksteden A, Hammes D, Schumacher F, Besenius E, Sperlich B, et al. Reliability of time-to-exhaustion and selected psycho-physiological variables during constantload cycling at the maximal lactate steady-state. Applied Physiology Nutrition and Metabolism. 2017;42(2):142-147. https://doi.org/10.1139/apnm-2016-0375

54.World Medical Association Declaration of Helsinki: Ethical Principles for Medical Research Involving Human Subjects. JAMA. 2013;310(20):2191. https://doi.org/10.1001/jama.2013.281053

55.International Standards for Anthropometric Assessment. [Internet] 2001 Apr 8 [cited 2018 Apr 28]. Available from: http://www.ceap.br/material/MAT17032011184632.pdf

56. Global Database on Body Mass Index an interactive surveillance tool for monitoring nutrition transition. [Internet] 2018 Apr 28 [cited 2018 Apr 28]. Available from: http://apps.who.int/bmi/index.jsp

57.WHO: Memorandum of the meeting convened by USAID, WHO, PAHO and Mother Care Organization ("Mother Care"). The use of anthropometry in women for predicting 
pregnancy outcomes. WHO Bulletin, 1991;9(5):11-21.

58.Robinson BF. Relation of Heart Rate and Systolic Blood Pressure to the Onset of Pain in Angina Pectoris. Circulation. 1967;35(6):1073-83. https://doi.org/10.1161/01.CIR.35.6.1073

59.Ikonomi E, Daulle E, Çerra E, Canaj F, Correlation of Anthropometric Indicators to Vital Capacity of Young Sportsmen. International Journal of Science and Research (IJSR). 2016;5(7):608-14. https://doi.org/10.21275/v5i7.ART2016264

60.Nikitina OS, Yevsey AV, Narezkina LP, Pereverzev VA. Normal physiology. Practicum manual for specialty "Stomatology”. Minsk: BSMU; 2016. (in Russian)

61.Matiegka J. The testing of physical efficiency. American Journal of Physical Anthropology. 1921;4(3):223-30. https://doi.org/10.1002/ajpa.1330040302

62.Council of Europe. Testing physical fitness: Eurofit experimental battery-provisional handbook, Strasbourg: The Council; 1983.

63.PCFSN. The president's challenge: Physical fitness test. [Internet] 2011 July 14 [cited 2018 Apr 28]. Available from: https://www.presidentschallenge.org/challenge/physical/ index.shtml

64.Nosko M, Razumeyko N, Iermakov S, Yermakova T, Correction of 6 to 10-year-old schoolchildren postures using muscular-tonic imbalance indicators. Journal of Physical Education and Sport, 2016;16(3): 988-999. https://doi.org/10.7752/jpes.2016.03156

65.Olafsdottir AS, Torfadottir JE, Arngrimsson SA. Health Behavior and Metabolic Risk Factors Associated with Normal Weight Obesity in Adolescents. PLOS ONE. 2016;11(8):e0161451. https://doi.org/10.1371/journal.pone.0161451

66. Aminova OS, Uvarova IuE, Tiatenkova NN. Estimating dietary intake and nutritional status of students. In the World of Scientific Discoveries, 2017;9(1):66-74.

67.Egorycheva EV, Musina SV. Study of deviations bodi weight in today's college students. Sovremennye issledovaniia social'nykh problem, 2011;8(4):57-63. (in Russian)

68.Solodovnikova IuV, Metina KI, Sakharova OB, Kiku
PF, Babko SV. Nutrition and physical development of students (retrospective evaluation). Health Medical ecology Science, 2017;1(68):19-25. (in Russian) https://doi.org/10.5281/zenodo.345608

69.Razmus M, Razmus W. Evaluating the psychometric properties of the Polish version of the Body Appreciation Scale-2. Body Image. 2017;23:45-49. https://doi.org/10.1016/j.bodyim.2017.07.004

70.Choi JS, Kim JS. Mediating Effect of Body Image Distortion on Weight Loss Efforts in NormalWeight and Underweight Korean Adolescent Girls. Journal of School Health. 2017;87(3):217-224. https://doi.org/10.1111/josh.12483

71.Krucevich TYu, Bezverkhnia GV. Recreation in physical culture of different population groups. Kiev: Olympic Literature; 2010. (in Ukrainian)

72.Appak GA, Callagova RB. Features of a functional condition of cardiovascular system of students of 17-18 year-oldss with various somatotypes. VInternational congress "Person, Sport, Health" on April 21-23, 2011. St. Petersburg: 2011. P. 49-55. (in Russian)

73. Vivian Heyward, Ann Gibson. Advanced Fitness Assessment and Exercise Prescription. 7th Edition With Online Video. Human Kinetics; 2014.

74.Ribeiro-Silva RD, Fiaccone RL, da Conceicao-Machado MEP, Ruiz AS, Barreto ML, Santana MLP. Body image dissatisfaction and dietary patterns according to nutritional statusinadolescents. JornalDePediatria.2018;94(2):155-161. https://doi.org/10.1016/j.jped.2017.05.005

75.Yayan EH, Celebioglu A. Effect of an obesogenic environment and health behaviour-related social support on body mass index and body image of adolescents. Global Health Promotion. 2018;25(3):33-42. https://doi.org/10.1177/1757975916675125

76.Iakubovskij DA, Zimnickaia RE. Substantiation of directions of 25-35 years women fitness training of various somatic with an average level of physical fitness. Vestnik Polockogo gosudarstvennogo universiteta, 2015;15:127-133. (in Russian)

77.Kalashnikov DG, Tkhorevskij VI. Theory and technique of fitness training. Moscow: Francheter; 2010. (in Russian)

\section{Information about the authors:}

Kolokoltsev M.M. (Corresponding author); http://orcid.org/0000-0001-6620-6296; mihm49@mail.ru; Irkutsk National Research Technical University; ul. Lermontov 83, Irkutsk, 664074, Russia.

lermakov S.S.; http://orcid.org/0000-0002-5039-4517; sportart@gmail.com; Department of Tourism and Recreation, Gdansk University of Physical Education and Sport; Kazimierza Górskiego 1, 80-336 Gdańsk, Poland.

Cite this article as:

Kolokoltsev MM, lermakov SS. Morphofunctional and motor characteristics of Baikal region's students (Russia) with overweight. Pedagogics, psychology, medical-biological problems of physical training and sports, 2019;23(1):4-13. https://doi.org/10.15561/18189172.2019.0101

The electronic version of this article is the complete one and can be found online at: https://www.sportpedagogy.org.ua/index.php/PPS/issue/archive

This is an Open Access article distributed under the terms of the Creative Commons Attribution License, which permits unrestricted use, distribution, and reproduction in any medium, provided the original work is properly cited (http://creativecommons.org/licenses/by/4.0/deed.en).

Received: 15.01.2019

Accepted: 10.02.2019; Published: 27.02.2019 